\title{
Urbanization and Human Capital Development in Malaysia
}

Eny Lestari Widarni

(STIE Jaya Negara Tamansiswa Malang)

Claudia Laura

(European School of Economics)

\begin{abstract}
This paper investigates the impact of urbanization in Malaysia and human capital development in Malaysia in particular urbanized areas. We argue that the presence of urbanites at the turn of the 20th century has had a positive impact on human capital in Malaysia today. This is evidenced by empirical evidence using the Ordinary Least Squares (OLS) method by adopting the Índice Firjan de Desenvolvimento Municipal (IFDM) method to calculate the human capital development index in Malaysia. We find that the urbanization program has a positive impact on human capital development in Malaysia.
\end{abstract}

Keywords: IFDM, OLS, Urbanization, Human Capital

\section{Background}

The economic position of Malaysian society today spans a wide range, Malaysia has a unique or unusual diverse group with diverse ethnicities and cultures. The aim of this paper is to describe the channels through which urbanization programs can influence human capital formation in Malaysia. To do so, we studied the characteristics of urban skills in the urbanization period 1969 to 2019 which may affect the demand and supply for education in the first few decades after their arrival and the mechanisms of urban persistence and skills in managing urbanized land.

The literature on the long-term economic effects of the turn of the 20th century, urbanization in Malaysia has grown significantly in the last decades Since human capital is a major determinant of economic development (Bucci, et al., 2019), the question of what determines or builds it is a question. which is very relevant. The motivation of this paper is to understand the long-term effects of demographic change by studying specifics. National cultural characteristics, here defined narrowly, as customary beliefs and values passed on by ethnic, religious and social groups that have not changed from generation to generation. Although we do not imply that our statistical analysis is evidence of causality, we provide historical evidence of immigrant heterogeneity in the "market" for education and estimate the effect of historical immigration on current human capital. We used a simple OLS model and found that although the immigration effect was positive, it also depended on the nationality of the groups. We address a potentially serious endogeneity issue. This urbanization episode did not occur directly as a result of changes in the workforce (Kebschull, 2020). The influence of their presence on the formation of human capital in Malaysia has changed the face of Malaysia. Immigrant's high initial 
human capital, measured by a higher numerical score in 1969, has a spillover effect throughout the economy.

The human capital possessed by urbanites has a higher level effect on the accumulation of human capital they have, meaning that the human capital stock increases per capita as urbanites on average mingle and assimilate with local residents both formally and informally including education and training that is better because of the assimilation of culture, knowledge and skills. Urbanization increases the level of entrepreneurship in Malaysia, which means that entrepreneurial immigrants are more likely to educate themselves and their families so that they can develop including developing their economic conditions. The human capital of urbanites has spread to the indigenous population as they initiate successful behaviour as migrants. Human capital owned by urbanites can have positive implications for intergenerational transfers. The experience of urbanites can change the importance of education and create economic growth (Genevey et al,2013).

We formulate our main hypothesis, that the effect of urban presence on the formation of human capital is heterogeneous between groups of urbanites and local residents through a process of assimilation. At this point, we limit our empirical analysis to the main hypothesis without explicitly testing these mechanisms, although we are encouraged by the possibility to explore these questions empirically on a smaller scale in the future. Such as the extent to which universal access to general education is available in urban areas of Malaysia of origin, the religious affiliation of each group, religious education, and demographics of urban population and assimilation of urbanites with local residents. The level of social capital available in each urban community and the size of the community encourages the creation of cultural and knowledge exchanges between urbanites and local residents.

\section{Literature Review}

The available education is endogenous to human capital development (Lightfoot-Rueda, et al., 2016). In the case of the implementation of exogenous formal education, the longer the period of exposition to public education and the wider this provision, the more likely it is that citizens will expect the provision of education in migrant areas in the future (Erb, et al., 2013). The religious and cultural affiliation has received little attention from social scientists trying to understand its relationship to the formation of human and social capital. A common argument is that religiosity has a positive influence both by operating as a community organizer and motivator (Thomä, et al., 2014). The difference in religious affiliation in the context of this paper from its standard treatment in social capital research is that the religious mechanism highlighted in this paper rests on the different roles of religious education among urban communities. The desire for religious preservation is the driving force for the demand for education such as Islamic boarding schools for the Muslim community and churches for the Catholic community as well as centres for other religious education in urban areas in accordance with the religions and beliefs of the group.

The element of religiosity is present in almost all groups of immigrants, except for non-religious groups. The relationship between religious affiliation and the social context in which these urban groups find themselves may explain much more of the variation in the formation of human capital than the relationship between religiosity and social capital. The further away a person's religion is from a Muslim group that makes up the majority of the population in Malaysia, the more likely that community is involved in religious education. In addition, the more closely the concept of group 
identity is related to religion and religious traditions, the more likely it is that the community will organize schools or religious education.

urbanites who already have a family create different educational demands from young single urban men (Cohen \& Sirkeci, 2011). Urban groups with families and early childhood have a greater incentive to invest in education and to pressure local politicians to get school opportunities for their children than young single men who tend to work hard to prepare for the future those on urbanized land, which are more likely to return to their home areas. Local governments that need to maintain a workforce within their jurisdiction will be more likely to invest in public education if urban groups have a higher proportion of families. The widest mechanism by which national urbanization traits can supply education is social capital. Social capital is a persistent and shared belief and value that helps a group overcome the problem of free riders in pursuing activities of social value. Unlike a broader definition of social capital, civil capital includes only informal institutions that facilitate coordination within groups to solve long-lasting and collective action problems. There are two main ways in which social capital affects the provision of education and thus contributes to the formation of human capital. First, social capital increases the cost of free-driving behaviour in urbanized groups and thereby increases the ability of these groups to organize into associations to provide education and other services to the community, by reducing externalities. Urban associations are essential for the provision of early education in urbanized areas., where public provision is scarce because urbanized areas generally tend to be still empty.

Social capital can be used to take advantage of a group's ability to generate political pressure and obtain public goods through the political process (Caramani, 2014). Social capital increases the introduction of elections in terms of public goods provided by the government. More generally, they suggest that existing informal institutions can play an important role in determining the success of formal political institutions.

The shift from informal to formal institutions is fundamental to understanding the persistence of the heterogeneous effect of national characteristics in Malaysia, namely the diversity of Malaysian ethnicities and cultures. Urban associations can influence politicians to increase education spending at the local level, turning social capital into political capital over time. In areas where the social capital of the urbanites is low, such a transformation does not occur. The effectiveness of each group's ability to organize depends on the size of each community in an area.

\section{Research methods}

In the previous section, we described the mechanisms by which immigrant groups can influence the formation of human capital in Malaysia. We hypothesize that a greater positive effect on the formation of human capital will occur in urbanization as a result of the assimilation of culture and skills between urbanites and local residents.

To test our hypothesis empirically, we use secondary data from Malaysia's Central Statistics Agency which is triangulated with data from the world bank as well as data from the Social, Labor and Urbanization Service related to education ranging from kindergarten, primary, secondary and tertiary education. from 1969 to 2019, We also investigated Malaysian demographic data from 1967 to 2019. Health, employment \& income data in Malaysia. We process all data by adopting processed immigrant data in Brazil Índice Firjan de Desenvolvimento Municipal 2018. We process education, health, 
employment and income data into an index which we make as a dependent variable which we call IFDM which stands for Índice Firjan de Desenvolvimento Municipal.

Índice Firjan de Desenvolvimento Municipal is an index used in Brazil taking into account employment and income, education and health which are the main components of forming human capital. In the IDFM employment and income are calculated by considering the generation of formal jobs, the level of formalization, the job market, income, real wage claims on the market, formal employment and the Gini index of income inequality informal jobs. The education includes the frequency of school-age children, the number of elementary school dropouts, the distortion of class age in primary schools, teachers with higher education in primary schools, the average daily lesson hours in primary schools, the results of the education development index in primary schools For health, consider the proportion of adequate prenatal care, death due to unknown causes, infant mortality due to preventable causes, hospitalization that is sensitive to primary care (Vieira, 2018).

To estimate the influence of urbanites on human capital, a simple OLS model is used which adopts the research of Craig and Faria (2020) as follows:

$\mathrm{IFDM}_{\mathrm{t}}=\mathrm{C}_{\mathrm{t}}+\beta_{1} \mathrm{P}_{\mathrm{t} 1}+\beta_{2} \mathrm{AL}_{\mathrm{t} 2}+\beta_{3} \mathrm{SH}_{\mathrm{t} 3}+\beta_{4} \mathrm{TL}_{\mathrm{t} 4}+\beta_{5} \mathrm{GDPP}_{\mathrm{t} 5}+\mathrm{e}_{\mathrm{t}}$

Where,

IFDM = Human capital index adopts Índice Firjan de Desenvolvimento Municipal

$\mathrm{P}=$ Education

$\mathrm{AL}=$ Assimilated Literacy

$\mathrm{SH}=$ Basic Education Participation

$\mathrm{TL}=$ Urbanization Literacy

GDPP $=$ Gross Domestic Product Per Capita

\section{Results and Discussion}

The estimation results are as follows:

$\mathrm{IFDM}=0.471341+0.638012 * \mathrm{AL}+1.012511 * \mathrm{GDPP}+1.542112 * \mathrm{P}+0.876354 * \mathrm{SH}+0.875954 * \mathrm{TL}$

From the OLS estimation results, the Assimilation Literacy (AL) affects the human capital development index in Malaysia by 0.638012 . If the assimilated literacy in Malaysia increases by $1 \%$, the human development index will also increase by 0.638012. Per Capita Gross Domestic Product has a positive effect along with other variables. Table 1 describes the estimation results as follows:

Table 1. Estimation Results

\begin{tabular}{|l|l|l|l|}
\hline \multicolumn{5}{|l|}{ Dependent variable IFDM } & Coefficient & t-Statistic & Prob. \\
\hline Variable & 0.471341 & 2.232926 & 0.0008 \\
\hline C & $6.43 \mathrm{E}-01$ & -0.686029 & 0.5039 \\
\hline AL & $1.01 \mathrm{E}+00$ & -0.922318 & 0.372 \\
\hline GDPP & 1.542112 & $3.58 \mathrm{E}+14$ & 0.0241 \\
\hline P & 0.876354 & 2.655914 & 0.0217 \\
\hline SH & 0.875954 & -2.7151 & 0.0003 \\
\hline TL & 0.781253 & Mean dependent var & 73.75184 \\
\hline R-squared & & \\
\hline
\end{tabular}




\begin{tabular}{|l|l|l|l|}
\hline Adjusted R-squared & 0.776204 & S.D. dependent var & 44.6114 \\
\hline S.E. of regression & 202.5159 & Sum squared resid & $8.41 \mathrm{E}-26$ \\
\hline F-statistic & 902.0832 & Durbin-Watson stat & 0.903212 \\
\hline Prob(F-statistic) & 0 & & \\
\hline
\end{tabular}

The estimation results and table 1 indicate that urbanization that occurred in Malaysia from 1969 to 2019 had a positive impact on Malaysia's human capital development.

\section{Conclusion}

The Urbanization Program from 1967 to 2019 in Malaysia has a positive impact on the development of human capital in Malaysia.

\section{Reference :}

Bucci,A., Prettner,K. ,Prskawetz,A.(2019).Cham : Springer

Caramani,D.(2014).Comparative Politics.Oxford : Oxford University

Cohen,J.H., Sirkeci,I.(2011).Cultures of Migration: The Global Nature of Contemporary Mobility. Austin: University Of Texas Press

Craig,J.D., Faria,A.B. (2020).Immigrant nationality and human capital formation in Brazil.International Journal of Educational Development,1(80),1-14. https://doi.org/10.1016/j.ijedudev.2020.102260

Erb,M., Faucher,C. ,Sulistiyanto,P.(2013).Regionalism in Post-Suharto Malaysia.London : Routledge

Genevey,R., Pachauri,R.K. ,Tubiana,L.(2013).Reducing Inequalities: A Sustainable Development Challenge.New Delhi : The Energy and Resources Institute.

Kebschull,D.(2020).Transmigration in Malaysia.London : Routledge

Lightfoot-Rueda,T., Peach,R.L. ,Leask,N.(2016).Global Perspectives on Human Capital in Early Childhood Education. Cham : Springer

Nielsen,K.B, Oskarsson,P.(2016).Industrialising Rural India: Land, policy and resistance.London : Taylor \& Francis

Thomä,D., Henning,C. ,Schmid,H.B.(2014).Social Capital, Social Identities: From Ownership to Belonging.Berlin :De Gruyter

Vieira, E.E.G. (2018).IFDM 2018 ÍNDICE FIRJAN DE DESENVOLVIMENTO MUNICIPAL Ano Base 2016. Rio de Janeiro : Firjan 